\title{
TGF- $\beta$ induces Smad2 Phosphorylation, ARE Induction, and Trophoblast Differentiation
}

\author{
Renee E. Albers ${ }^{1, *}$, Kaisa Selesniemi ${ }^{1, *}$, David R.C. Natale ${ }^{2}$, Thomas L. Brown ${ }^{1}$ \\ ${ }^{I}$ Department of Neuroscience, Cell Biology and Physiology, Wright State University Boonshoft School of Medicine, Dayton, Ohio 45435, USA \\ ${ }^{2}$ Department of Reproductive Medicine, University of California-San Diego, San Diego, California 92093, USA
}

Background: Transforming growth factor beta (TGF- $\beta$ ) signaling has been shown to control a large number of critical cellular actions such as cell death, differentiation, and development and has been implicated as a major regulator of placental function. SM10 cells are a mouse placental progenitor cell line, which has been previously shown to differentiate into nutrient transporting, labyrinthine-like cells upon treatment with TGF- $\beta$. However, the signal transduction pathway activated by TGF- $\beta$ to induce SM10 progenitor differentiation has yet to be fully investigated.

Materials and Methods: In this study the SM10 labyrinthine progenitor cell line was used to investigate TGF- $\beta$ induced differentiation. Activation of the TGF- $\beta$ pathway and the ability of TGF- $\beta$ to induce differentiation were investigated by light microscopy, luciferase assays, and Western blot analysis.

Results and Conclusions: In this report, we show that three isoforms of TGF- $\beta$ have the ability to terminally differentiate SM10 cells, whereas other predominant members of the TGF- $\beta$ superfamily, Nodal and Activin A, do not. Additionally, we have determined that TGF- $\beta$ induced Smad2 phosphorylation can be mediated via the ALK-5 receptor with subsequent transactivation of the Activin response element. Our studies identify an important regulatory signaling pathway in SM10 progenitor cells that is involved in labyrinthine trophoblast differentiation.

Keywords: Placenta, Labyrinthine, TGF- $\beta$, Differentiation, Smad

Received: November 24, 2017, Revised: February 19, 2018, Accepted: February 19, 2018, Published online: April 30, 2018 Correspondence to Thomas L. Brown

Department of Neuroscience, Cell Biology and Physiology, Wright State University Boonshoft School of Medicine and the College of Science and Mathematics, 3640 Colonel Glenn Highway, 457 Neuroscience Engineering Collaboration Building, Dayton, Ohio 45435, USA

Tel: +1-937-775-3809, Fax: +1-937-775-3391

E-mail: Thomas.L.brown@wright.edu

$\star$ These authors contributed equally to this work.

(c) This is an open-access article distributed under the terms of the Creative Commons Attribution Non-Commercial License (http://creativecommons.org/ licenses/by-nc/4.0/), which permits unrestricted non-commercial use, distribution, and reproduction in any medium, provided the original work is properly cited.

Copyright (c) 2018 by the Korean Society for Stem Cell Research

\section{Introduction}

The placenta is an essential organ that is formed transiently during mammalian pregnancy. It enables the transport of nutrients, gases, and wastes between the mother and the developing fetus (1). In order to maintain a healthy pregnancy, the placenta must properly develop into the appropriate trophoblast lineages (2). Abnormal placental development is associated with a reduction in placental function and pregnancy-associated disorders, such as fetal growth restriction (FGR), placental insufficiency and/or preeclampsia (3).

Both human and rodent studies have investigated the underlying pathways that regulate placental differentiation and development. TGF- $\beta$ signaling has been implicated as a possible regulator of placental development and dysfunction, as all three TGF- $\beta$ isoforms have been shown to be elevated in human preeclamptic pregnancies (4-6). TGF- $\beta$ has been shown to regulate a large number 
of critical cellular actions such as cell growth, differentiation, lineage determination, extracellular matrix restructuring, and apoptotic cell death (7).

TGF- $\beta$ signals through type I and type II receptors that heterodimerize and phosphorylate Smad proteins (8). Loss of the primary type I receptor for TGF- $\beta$, Activin-receptor Like Kinase 5 (ALK5 or $\mathrm{T} \beta \mathrm{RI}$ ), is embryonically lethal and the loss of type II receptor, TGF- $\beta$ RII, is perinatally lethal $(9,10)$. TGF- $\beta$ can signal through phosphorylation of either of two receptor-regulated Smads (R-Smads), Smad2 or Smad3, which can then dimerize with Smad4 allowing for nuclear translocation and binding to response elements that activate downstream signaling pathways (11). Knockout studies have shown that both Smad2 and Smad4 are embryonically lethal, whereas, ablation of Smad3 results in viable offspring, indicating some non-overlapping function of the regulatory Smads (12). In addition to R-Smads, inhibitory Smads (I-Smads) can also affect the signal transduction pathway induced by TGF- $\beta$. Smad7 is upregulated by TGF- $\beta$ and has the ability to inhibit signaling of the TGF- $\beta$ family through a negative feedback loop $(13,14)$. Studies in mice have found that a Smad7 deficiency can also result in strain-dependent defects in mice ranging from decreased adult size to perinatal death, indicating that the entire TGF- $\beta$ signal transduction pathway is essential to proper development and embryonic survival (13).

As the rodent placenta has numerous structures and functions that are comparatively similar to the human placenta, mouse models have been useful in establishing the importance of TGF- $\beta$ and Smad proteins in placental development $(12,15)$. Placental labyrinthine cells are closest to the fetus and are important for the transport of nutrients and wastes between the mother and developing fetus $(16,17)$. SM10 cells are a mouse labyrinthine progenitor cell line, which have been previously shown to differentiate after treatment with TGF- $\beta$ and can be used as a model for the transport layer of the placenta (18-21). The pathway activated by TGF- $\beta$ to induce SM10 progenitor differentiation, however, has yet to be fully investigated. Our previous studies have shown that TGF- $\beta$ induced down regulation of the stem cell regulator, Id2, is necessary for SM10 trophoblast progenitor differentiation (20). In this study, we show that all three TGF- $\beta$ isoforms have the ability to terminally differentiate SM10 cells, whereas other members of the TGF- $\beta$ superfamily, i.e. Activin A and Nodal, do not. Additionally, we have identified that TGF- $\beta$ signaling in SM10 placental labyrinthine cells is primarily induced via Smad2 phosphorylation and transactivation of the Activin response element, in con- trast to the more classical activation of 3TP and SBE promoter response elements, to alter gene expression necessary to induce differentiation.

\section{Materials and Methods}

\section{Materials}

RPMI1640/L-glutamine, DMEM/High glucose, $2 \beta$-mercaptoethanol (35602), antibiotic-antimycotic (SV30079.01) and Supersignal West Pico Chemiluminescence Substrate (34080) were purchased from Thermo Scientific. Sodium pyruvate (25-000-CI) was purchased from Mediatech Inc. Fetal Bovine Serum (FBS) (S01520) was purchased from Biowest. Metafectene transfection reagent (T020) was purchased from Biontex Laboratories (Germany). ${ }^{3}[\mathrm{H}]-2-\mathrm{deo}-$ xyglucose was purchased from MP Biochemicals. TGF- $\beta 1$ (240-B), TGF- $\beta 3$ (243-B3), Nodal (1315-ND-025CF) and Activin A (338-AC) were obtained from R\&D Systems. TGF- $\beta 2$ was kindly provided by Dr. Steven Ledbetter (Genzyme). SB 431542 (\#1614) was purchased from Tocris. The 3TP-lux reporter has been previously described (22, 23). Anti-Smad2 rabbit polyclonal (51-1300), rabbit polyclonal anti-Smad3 (51-1500), were purchased from Zymed. Rabbit polyclonal anti-phosphoSmad3 was a kind gift of Dr. Ed Leof, Mayo Clinic (24). Mouse monoclonal anti-Smad4 (B8)(sc-7966) and rabbit polyclonal anti-phosphoSmad2 (06-829) were purchased from Santa Cruz Biotechnology and Upstate Biotechnology, respectively. The secondary antibodies anti-rabbit IgG (W401B) and anti-mouse IgG (W402B) were purchased from Promega. The pcDNA3 vector was obtained from Invitrogen.

\section{Cell culture and trophoblast differentiation}

Mouse SM10 cells were maintained in RPMI1640/L-glutamine medium supplemented with $1 \mathrm{mM}$ sodium pyruvate, $50 \mu$ M $2 \beta$-mercaptoethanol, $1 \%$ antibiotic-antimycotic, and $10 \%$ FBS (18-21). SM10 cells were treated with TGF$\beta 1(5 \mathrm{ng} / \mathrm{ml})$, TGF- $\beta 2(5 \mathrm{ng} / \mathrm{ml})$, TGF- $\beta 3(2 \mathrm{ng} / \mathrm{ml})$, Activin A (5 ng/ml), Nodal $(250 \mu \mathrm{g} / \mathrm{ml})$, or vehicle $(4 \mathrm{mM}$ $\mathrm{HCl}, 0.5 \% \mathrm{mg} / \mathrm{ml} \mathrm{BSA}$ ) for $72 \mathrm{hrs}$ to induce differentiation. COS-7 cells were obtained from ATCC (CRL-1651) and were cultured in DMEM/High glucose, $10 \%$ heat inactivated fetal bovine serum, and 1\% antibiotic-antimycotic. All cell types were passaged at 80 90\% confluence.

\section{Receptor inhibition}

Inhibition of Alk receptors in SM10 cells was conducted by plating $3 \times 10^{5} \mathrm{SM} 10$ cells in p60s. Cells were then treated with or without the ALK-5 (TGF- $\beta$ receptor) specific inhibitor SB431542 (10 $\mu \mathrm{M})$ for 1 hour, followed by 
treatment without or with TGF- $\beta 2(5 \mathrm{ng} / \mathrm{ml})$ for 48 hours.

\section{Growth inhibition}

SM10 cells were plated at $1 \times 10^{5}$ cells $/ \mathrm{ml}$ in 24 well plates for $24 \mathrm{~h}$ prior to treatment. Cells were then treated with TGF- $\beta 2$ or Activin A for 72 hours and subsequently incubated with $1 \mu \mathrm{Ci} / \mathrm{ml}^{3} \mathrm{H}$-Thymidine (ICN) per well for $4 \mathrm{~h}$. The cells were washed twice with 10 per cent trichloroacetic acid (TCA) for $10 \mathrm{~min}$ and lysed by adding $300 \mu \mathrm{l}$ of $0.2 \mathrm{~N} \mathrm{NaOH}$ containing $40 \mu \mathrm{g} / \mathrm{ml}$ of salmon sperm DNA. Cell lysates $(100 \mu 1)$ were counted in Scintiverse scintillation fluid (8).

\section{Western blotting}

Western blotting was performed as previously described $(20,25)$ using rabbit polyclonal anti-Smad 2, rabbit polyclonal anti-Smad 3, mouse monoclonal anti-Smad4 (B8), rabbit polyclonal anti-phosphoSmad2, rabbit polyclonal anti-phosphoSmad3, or mouse monoclonal anti pan-actin (C4) antibodies at $1 / 500$ overnight at $4^{\circ} \mathrm{C}$ overnight in blocking buffer $(5 \%[\mathrm{w} / \mathrm{v}]$ non-fat milk, $\mathrm{pH} 7.4$ in $1 \mathrm{X}$ PBS containing $0.05 \%$ Tween-20 [1X PBST]). Following overnight incubation with primary antibody, the membrane was washed with 1xPBST, probed with HRP-conjugated anti-rabbit $\operatorname{IgG}$ or anti-mouse secondary antibody at 1/10,000 for 1 hour at RT, and visualized using Enhanced Chemi-Lumeniscence reagent according to manufacturer's
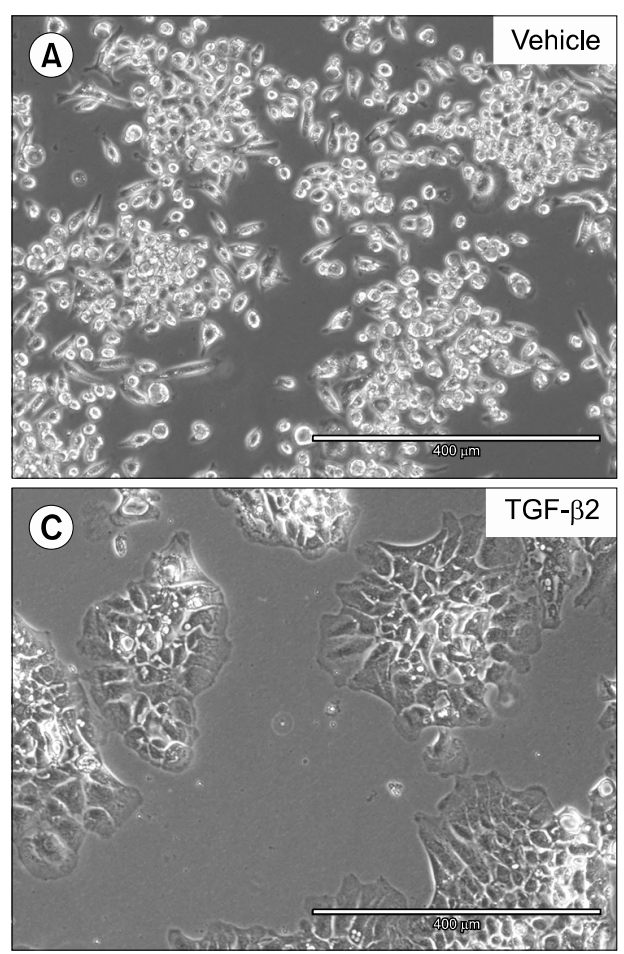

E

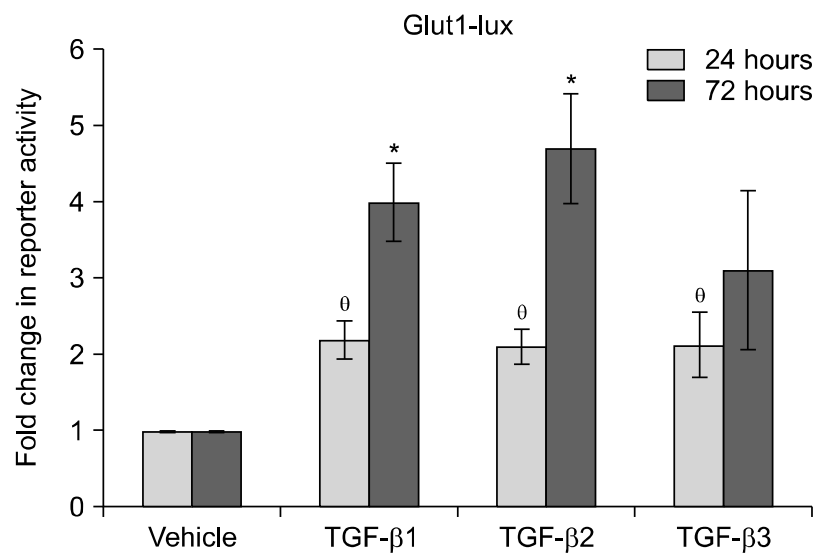

Fig. 1. TGF- $\beta$ isoforms induce trophoblast progenitor differentiation and Glut-1 transactivation. SM10 cells were treated for 72 hrs with (A) vehicle control, (B) $5 \mathrm{ng} / \mathrm{ml}$ TGF- $\beta 1$, (C) $5 \mathrm{ng} / \mathrm{ml} \mathrm{TGF-} \beta 2$, or (D) $2 \mathrm{ng} / \mathrm{ml}$ TGF- $\beta 3$ to induce differentiation. (E) Glut-1 luciferase reporter activity in SM10s cells treated with vehicle control, TGF- $\beta 1$, TGF- $\beta 2$, or TGF$\beta 3$. Cells were transiently transfected with Glut1-lux and pRLSV40 using Metafectene. Twenty-four hours post-transfection, cells were treated with vehicle control, TGF- $\beta 1$ (5 $\mathrm{ng} / \mathrm{ml})$, TGF- $\beta 2(5 \mathrm{ng} / \mathrm{ml})$, or TGF$\beta 3(2 \mathrm{ng} / \mathrm{ml})$ for 24 or 72 hours. Luciferase activity was analyzed using the dual luciferase assay system. The Glut1-lux transactivation values were normalized to the constitutively active reporter, pRLSV40. Error bars represent standard error of the mean. $(\theta)$ indicates a significant increase in Glut1 luciferase transactivation compared to vehicle control at 24 hours and $(*)$ indicates a significant increase from control at 72 hours. $p<$ 0.05 . 
instructions.

\section{Luciferase reporter transactivation}

SM10 cells were plated at $2 \times 10^{5}$ cells/well and were transfected the next day with $0.2 \mu \mathrm{g}$ pRLSV40 and either $1 \mu \mathrm{g}$ 3TP-lux; $1 \mu \mathrm{g}$ Glut1-lux; or $1 \mu \mathrm{g}$ ARE-lux and 0.8 $\mu \mathrm{g}$ hFAST1 for 24 hours. $1 \mu \mathrm{g} \mathrm{pCDNA3}$ or $1 \mu \mathrm{g} \mathrm{Smad} 2$ DNA were also transfected in designated assays using Metafectene transfection reagent, as previously described (26). The cells were placed in fresh media and vehicle or $5 \mathrm{ng} / \mathrm{ml}$ Activin A, or $5 \mathrm{ng} / \mathrm{ml} \mathrm{TGF}-\beta$ was added for 72 hrs, after which the cells were rinsed in 1XPBS, and analyzed using the Dual Luciferase Reporter system according to manufacturer's directions (27). All ARE-Luc values were normalized to pRLSV40 values.

\section{Statistical analysis}

All experiments were conducted a minimum of three times independently, with similar results. Quantitative data is represented by average \pm Standard Error of the Mean (SEM). Data was analyzed via GraphPad Prism 7.0. Statistical analysis for the Glut1-lux assay (Fig. 1E) and growth inhibition (Fig. 2E) was conducted by using one-way ANOVA followed by Dunnett's multiple comparisons test. No statistical analysis was required for Fig. 3. Statistical analysis for 3TP-lux assays were conducted by Student t-test (Fig. 4A). Statistical analysis for ARE-lux assays were conducted by two-way ANOVA with Tukey's
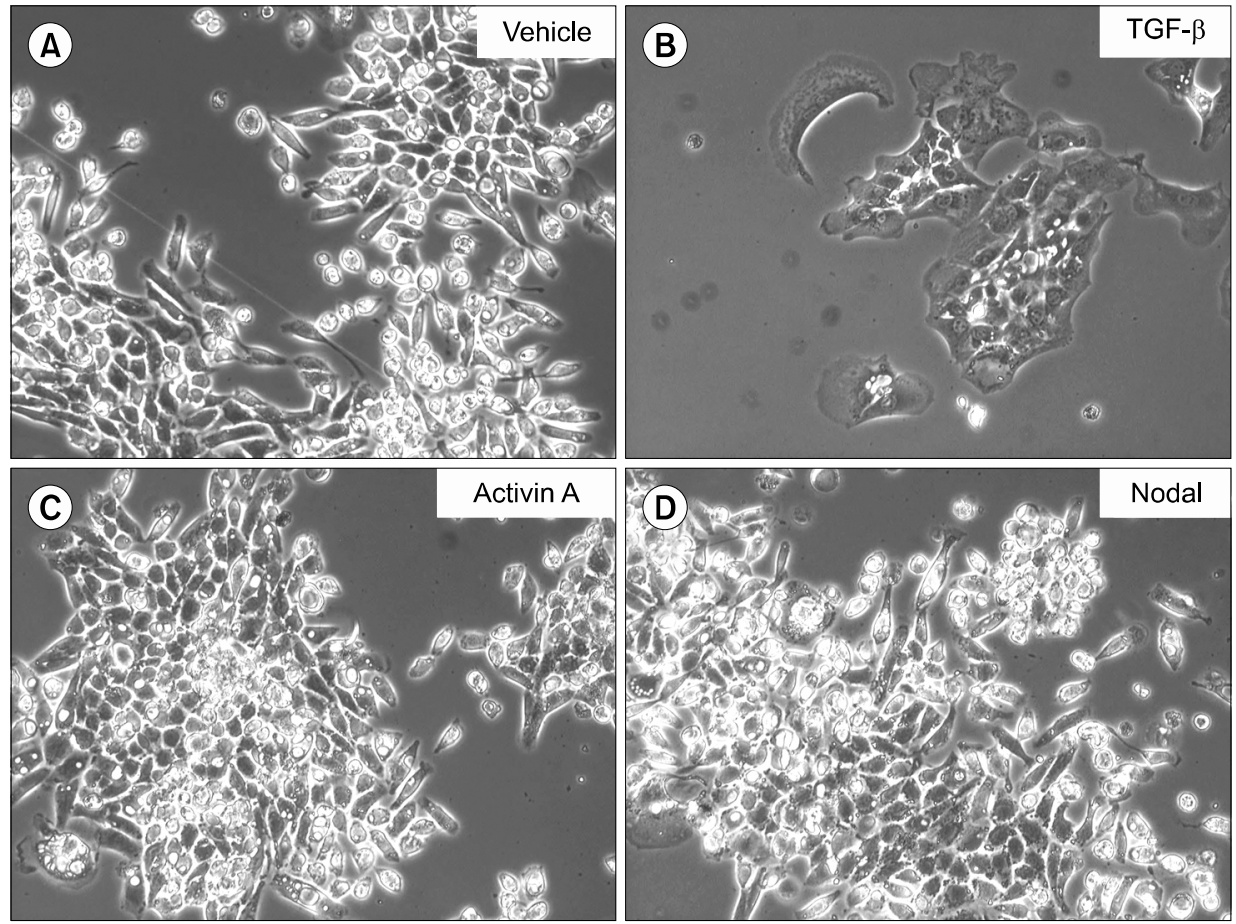

E

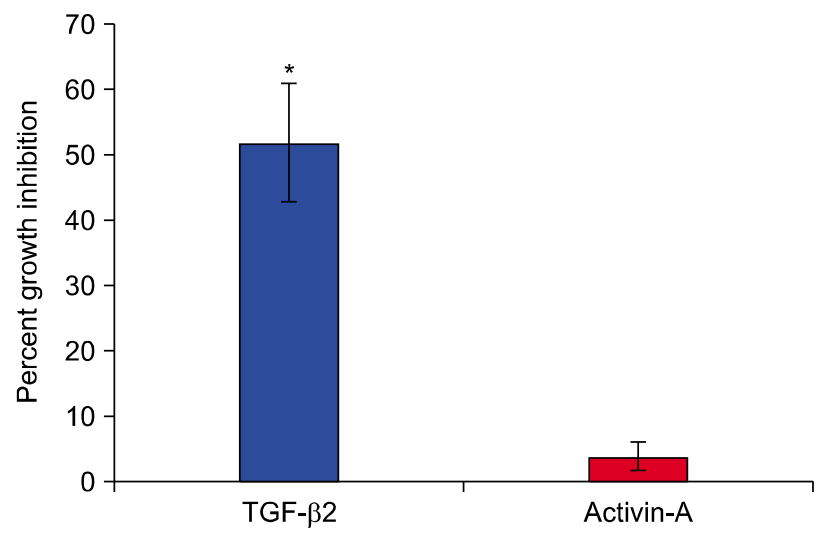

Fig. 2. TGF- $\beta$ induces SM10 cell differentiation and growth inhibition. SM10 cells were treated with $(A)$ vehicle control, (B) TGF- $\beta 2(5 \mathrm{ng} / \mathrm{ml})$, (C) Activin A (5 ng/ml), or (D) Nodal (250 $\mu \mathrm{g} / \mathrm{ml}$ ) for $72 \mathrm{hrs}$ to induce differentiation. (E) After 72 hours of treatment, cells were incubated with $1 \mu \mathrm{Ci} / \mathrm{ml}{ }^{3} \mathrm{H}$-Thymidine per well for 4 hours. Cells were then lysed and counted in scintillation fluid. Percent growth inhibition was determined as the amount of ${ }^{3} \mathrm{H}$-Thymidine incorporation compared to control. Percent growth inhibition is normalized to vehicle treated cells. Error bars represent standard error of the mean. ${ }^{*} \mathrm{p}<0.001$. 
post hoc test for Smad7 overexpression (Fig. 4F) and Sidak's multiple comparisons test for Smad 2 overexpression (Fig. 4E). P values for $95 \%$ confidence interval were calculated. $\mathrm{p}<0.05$ was considered significant and is denoted by ${ }^{\star}$ or ${ }^{\theta}$.

\section{Results}

\section{TGF- $\beta$ isoforms differentiate SM10 progenitor cells}

Previous studies have shown that transforming growth factor beta (TGF- $\beta$ ), and in particular TGF- $\beta 2$, has the ability to cause SM10 placental progenitor cells to differentiate into cells with labyrinthine trophoblast characteristics (19-21). In order to further understand the signal transduction mechanisms involved in placental labyrinthine cell differentiation, SM10 cells were treated with different TGF- $\beta$ isoforms ( $\beta 1, \beta 2$, or $\beta 3$ ) and cell morphology was examined by light microscopy. Vehicle-treated SM10 cells remained undifferentiated (Fig. 1A). TGF$\beta 1$, TGF- $\beta 2$, and TGF- $\beta 3$ isoforms all induced similar morphologic trophoblast differentiation, characterized by cell aggregation and colony formation, characteristic of the labyrinthine lineage, as we have previously reported (Fig. $1 \mathrm{~B} \sim \mathrm{D})(19-21)$.

In order to further investigate the ability of each TGF$\beta$ isoform to transcriptionally induce downstream targets in SM10 cells, luciferase assays were performed at 24 and 72 hours post TGF- $\beta$ treatment to assess the trans-
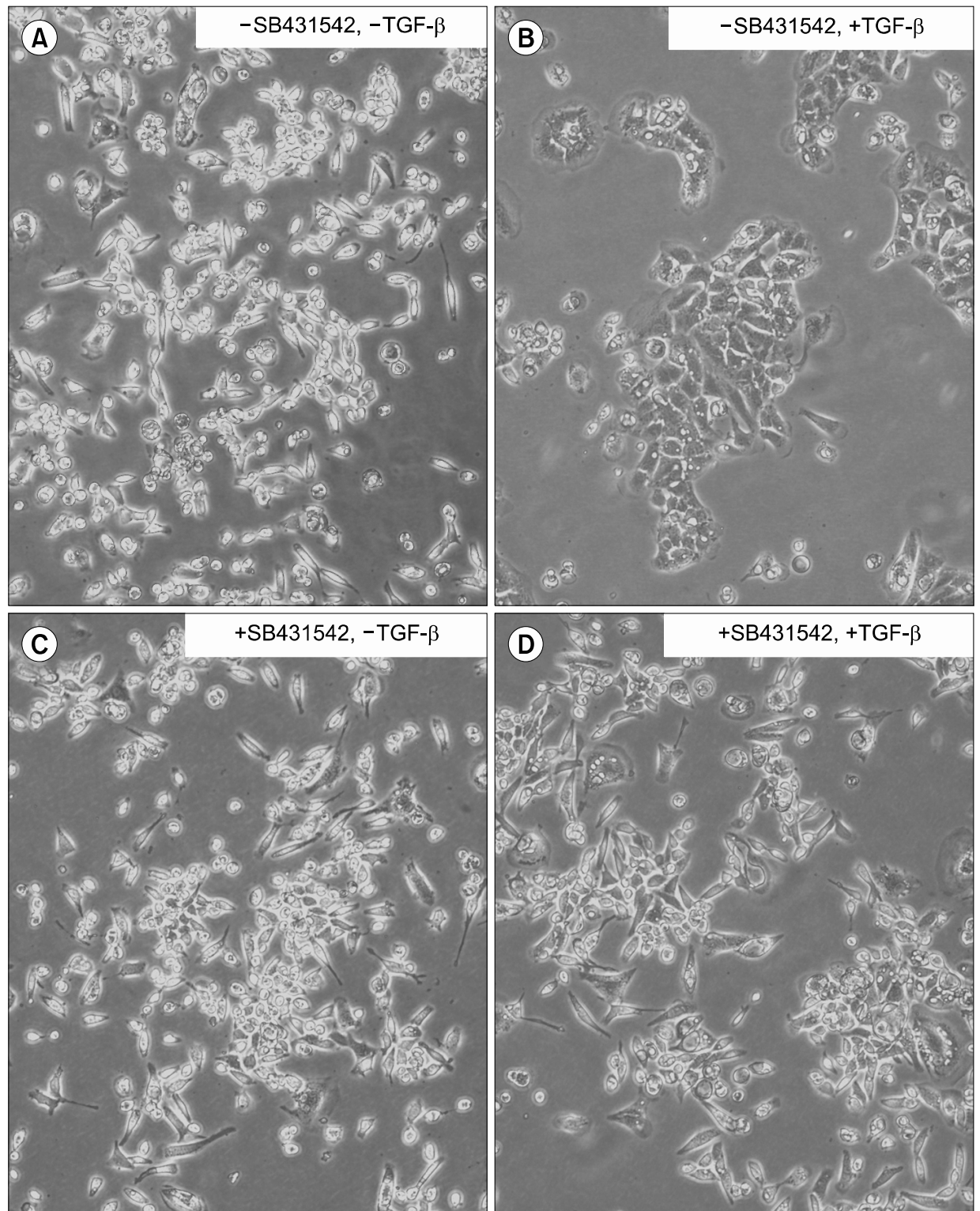

Fig. 3. TGF- $\beta$ induced differentiation can be mediated through the Alk-5 receptor. SM10 cells were treated without $(\mathrm{A}, \mathrm{B})$ or with $(\mathrm{C}, \mathrm{D})$ the Alk inhibitor SB431542 $(10 \mu \mathrm{M})$ for 1 hour, followed by treatment without $(\mathrm{A}, \mathrm{C})$ or with $(\mathrm{B}, \mathrm{D})$ TGF- $\beta$ $2(5 \mathrm{ng} / \mathrm{ml})$ for 48 hours. 
A

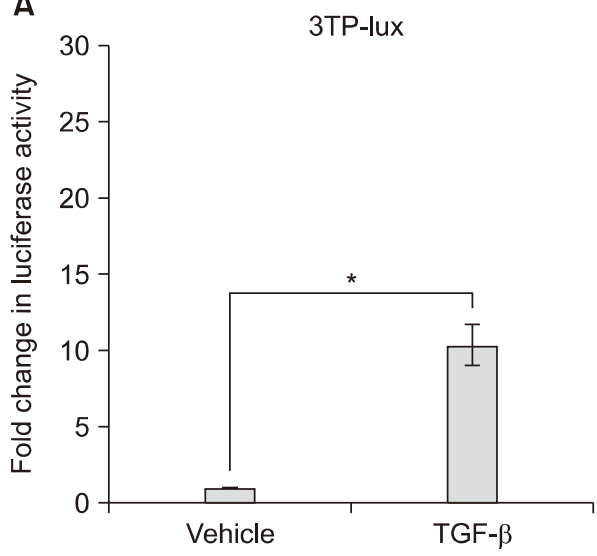

B

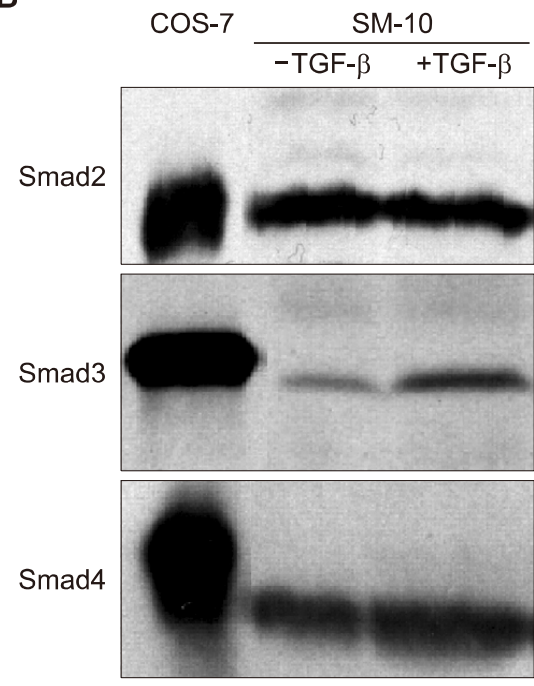

C

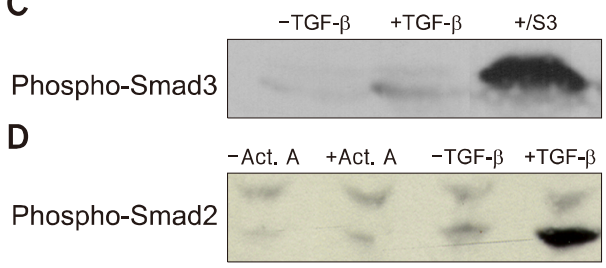

E

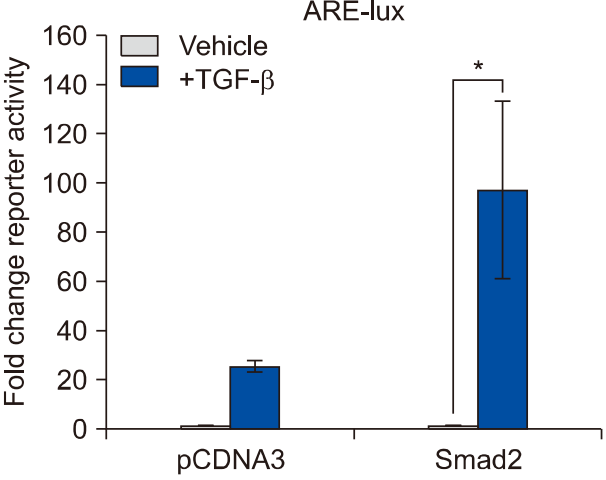

F

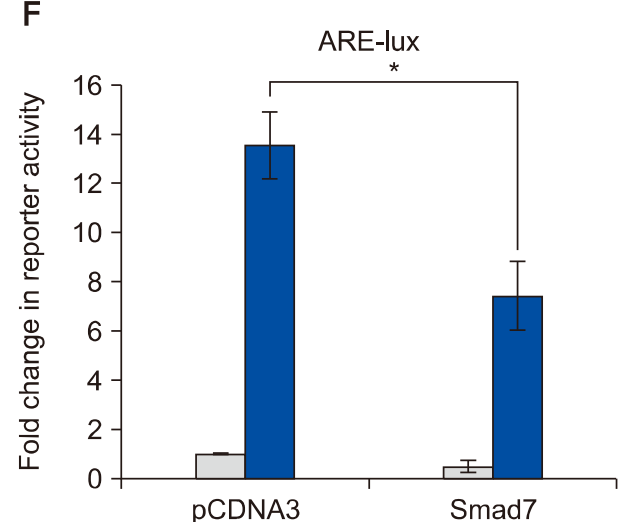

Fig. 4. TGF- $\beta$ triggers Smad2 phosphorylation and transactivation. (A) 3TP luciferase reporter activity in SM10s cells treated with vehicle control or TGF- $\beta$ 2. Cells were transiently transfected with 3TP-lux and pRLSV40 using Metafectene. Twenty-four hours post-transfection, cells were treated with vehicle or TGF- $\beta 2(5 \mathrm{ng} / \mathrm{ml})$ for 72 hours. Luciferase activity was analyzed using the dual luciferase assay system. The 3TP-lux transactivation values were normalized to the constitutively active reporter (pRLSV40). (B) Western blotting analysis of Smad2, Smad3, and Smad4 in TGF- $\beta 2$ or vehicle-treated SM10 cells. COS-7 cells were used as a positive control. (C) Western blotting analysis of Phospho-Smad3 in TGF- $\beta 2$ or vehicle-treated SM10 cells. COS-7 cells transiently transfected with the plasmid, pXIX-Smad3 and treated with TGF- $\beta$ were used as a positive control. (D) Western blotting analysis of Phospho-Smad2 in the TGF- $\beta 2$, Activin A, or vehicle-treated SM10 cells. (E) ARE luciferase reporter activity in SM10 cells transiently transfected with pCDNA3 control or pRK5-Smad2 and treated with vehicle control or TGF- $\beta 2$. Cells were transiently transfected with ARE-lux, pLv-CMV-hFAST-1, and pRLSV40 using Metafectene. Twenty-four hours post-transfection, cells were treated with vehicle or TGF- $\beta 2(5 \mathrm{ng} / \mathrm{ml})$ for 72 hours. Luciferase activity was analyzed using the dual luciferase assay system. The ARE-lux transactivation values were normalized to the constitutively active reporter (pRLSV40). (F) ARE luciferase reporter activity in SM10 cells transiently transfected with pCDNA3 control or pRK5-Smad7 and treated with vehicle control or TGF- $\beta$ 2. Cells were transiently transfected with ARE-lux, pLv-CMV-hFAST-1, and pRLSV40 using Metafectene. Twenty-four hours post-transfection, cells were treated with vehicle or TGF- $\beta 2(5 \mathrm{ng} / \mathrm{ml})$ for 72 hours. Luciferase activity was analyzed using the dual luciferase assay system. The ARE-lux transactivation values were normalized to the constitutively active reporter (pRLSV40). Error bars represent standard error of the mean. ${ }^{*} p<0.05$.

activation of glucose transporter 1, Glut-1. Previous studies have shown that TGF- $\beta$ has the ability to stimulate Glut-1 signaling $(28,29)$. In the current study, all three TGF- $\beta$ isoforms also exhibited similar rates of Glut-1 transcriptional activation after 24 hrs of treatment; however, TGF- $\beta 2$ exhibited the greatest activation at $72 \mathrm{hrs}$ and therefore was used to differentiate SM10 cells for the remaining experiments (Fig. 1E). 


\section{TGF- $\beta$, but not Activin A or Nodal, promote SM10 progenitor differentiation}

Since TGF- $\beta$ isoforms were capable of inducing SM10 cell progenitor differentiation, we investigated whether other predominant members of the TGF- $\beta$ superfamily, Activin A and Nodal, could promote differentiation. Vehicle treated cells did not differentiate, whereas cells treated with TGF- $\beta$ were differentiated as expected, as indicated by characteristic cell aggregation (Fig. 2A, B). Treatment with Activin A or Nodal was did not differentiate SM10 progenitors (Fig. 2C, D). As SM10 cells differentiate, their rate of proliferation decreases. Therefore, to assess the ability of Activin A and TGF- $\beta$ to inhibit cell proliferation, growth inhibition studies were conducted using ${ }^{3} \mathrm{H}$-thymidine. TGF- $\beta$ treatment induced $52 \%$ growth inhibition of SM10 cells, while Activin A had no effect on proliferative activity of SM10 cell progenitors (Fig. 2E).

\section{TGF- $\beta$ induced differentiation is dependent upon TGFBR1 signaling}

Further investigation of the signaling pathways governing TGF- $\beta$ dependent differentiation of SM10 progenitors were conducted by treating cells with SB431542 in the presence or absence TGF- $\beta$. SB431542 inhibits Activin Receptor-Like Kinases (ALKs): ACVR1B (ALK-4), TGFBR1 (ALK-5), and ACVR1C (ALK-7) (30). TGF- $\beta$ is known to signal through ALK-5, whereas Activin A signals through ALK-4, and Nodal via ALK-7 (31, 32). SM10 cells treated with vehicle or SB431542 alone did not differentiate (Fig. 3A, B), whereas cells treated with TGF- $\beta$ differentiated as expected (Fig. 3C). SM10 cells treated with both SB431542 and TGF- $\beta$, however, were unable to fully differentiate as indicated by the lack of colony formation (Fig. 3D). These data suggest that TGF- $\beta$ -induced SM10 differentiation can be mediated via ALK-5, as TGF- $\beta$ has not been reported to signal through either ALK-4 or ALK-7 (32).

\section{TGF- $\beta$ induces phosphorylation of Smad2 but not Smad3 in SM10 cells}

In order to examine the signaling pathways transcriptionally activated by TGF- $\beta$ induced differentiation in SM10 progenitor cells, luciferase assays with 3TP-lux reporter were conducted. 3TP-lux is a luciferase construct containing a luciferase reporter gene. It has three copies of the TPA response element (3TP) from the human collagenase gene and one TGF- $\beta$ response element from the human plasminogen activator inhibitor 1 (PAI-1) gene, which can be transcriptionally activated by TGF- $\beta$ (23). TGF- $\beta$ treatment of SM10 cells induced 3TP luciferase activity by approximately 10-fold (Fig. 4A).

Previous studies have shown that TGF- $\beta$ can signal through either Smad2 or Smad3 phosphorylation to induce cellular signaling. Both Smad2 and Smad3 are regulatory (R-Smads) that, once phosphorylated, can bind to Smad4, create a heterodimer, and translocate to the nucleus to activate gene transcription (33). In order to determine which R-Smads are activated by TGF- $\beta$-induced differentiation, SM10 cells were analyzed by Western blot for the presence of Smad2, Smad3, and Smad4 protein after TGF- $\beta$ or vehicle treatment (Fig. 4B). COS-7 cells were used as a positive control (Fig. 4B). Smad2, Smad3, and Smad4 were all present in undifferentiated SM10 progenitor cells. Additionally, TGF- $\beta$ treatment did not increase the levels of Smad2 and Smad4; however, TGF- $\beta$ treatment resulted in slightly increased levels of Smad3 protein.

While increased protein levels can often be helpful in understanding signaling transduction pathways, the activation of TGF- $\beta$ receptor signaling is propagated via phosphorylation of the R-Smads to ultimately allow for binding of Smad4 and transcriptional activation. To examine phosphorylation levels of Smad2 and Smad3; SM10 cells were treated with TGF- $\beta$ for 72 hours and analyzed by Western blot using phospho-specific antibodies (34). Phosphorylated Smad3 (phospho-Smad3) was weakly detected and present at very low levels in SM10 cells regardless of TGF- $\beta$ treatment (Fig. 4C). In contrast, phospho-Smad2 was substantially increased upon TGF- $\beta$ administration (Fig. 4D). These results clearly indicate that Smad2, but not Smad3, activation is induced by TGF- $\beta$ in SM10 cells during the process of differentiation. Activin A was not able to induce Smad2 phosphorylation in SM10 cells (Fig. 4D), consistent with its inability to induce SM10 progenitor differentiation.

\section{TGF- $\beta$ induces transactivation of Activin Responsive Element via Smad2}

To investigate TGF- $\beta$ signaling via phospho-Smad2, we examined 3TP and ARE (Activin Response Element) luciferase reporter assays, which have been shown to be activated by TGF- $\beta(22,35)$. Smad binding element reporter activity (SBE-lux) was not assessed due to the known preferential specificity for phospho-Smad3 and the lack of Smad3 activation in SM10 cells (Fig. 4C) (36). ARE activity induced by TGF- $\beta$ or Activin A was assessed using luciferase reporter assays using an ARE-lux construct in the presence of forkhead activin signal transducer-1 (FAST-1), as it is required for induction of the activin response element (35). We determined if ARE 
transactivation could be stimulated in SM10 cells by overexpressing Smad2 by transient transfection. SM10 cells transfected with control DNA (pCDNA3) and treated TGF- $\beta$ had an increased level of luciferase activity compared to SM10 cells treated with vehicle (Fig. 4E). Additionally, SM10 cells transiently transfected with a Smad 2 and subsequently treated with TGF- $\beta$ had a significant increase in ARE-lux activation compared to SM10 cells overexpressing Smad2 and treated with vehicle (Fig. $4 \mathrm{E})$. Therefore, TGF- $\beta$ treatment induces luciferase activity of the Activin response element in SM10 cells, and triggers the expression of genes involved in the regulation of cell growth and differentiation.

\section{Smad7 reduces activation of the activin responsive element}

To further investigate TGF- $\beta$ mediated transactivation of the Activin response element, SM10 cells were transiently transfected with ARE-lux, FAST1, and Smad7 and treated with TGF- $\beta$. Smad7 is an inhibitor of TGF- $\beta$ signaling that works by preventing R-Smad activation
(37). Smad7 is upregulated by TGF- $\beta$, and therefore, can act as part of a negative feedback loop (37). SM10 cells treated with TGF- $\beta$ increased ARE-lux transactivation in cells transfected with control DNA (pCDNA3) compared to vehicle treated cells (Fig. 4F). Overexpression of Smad7 via transient transfection in SM10 cells significantly inhibited TGF- $\beta$ induced transactivation of ARE-lux (Fig. $4 \mathrm{~F})$.

\section{Discussion}

Our previous studies have demonstrated the importance of stem cell regulator, Id2, in the regulation of trophoblast progenitor differentiation and have shown that Id 2 downregulation is necessary for TGF- $\beta$ induced differentiation in SM10 cells (20). As proper trophoblast differentiation of labyrinthine cells is critical for establishment of feto-maternal placental nutrient transport and the regulation of cell metabolism, we investigated the signaling mechanisms involved in TGF- $\beta$ induced differentiation of SM10 cells. Our data indicate that all three TGF- $\beta$ iso-

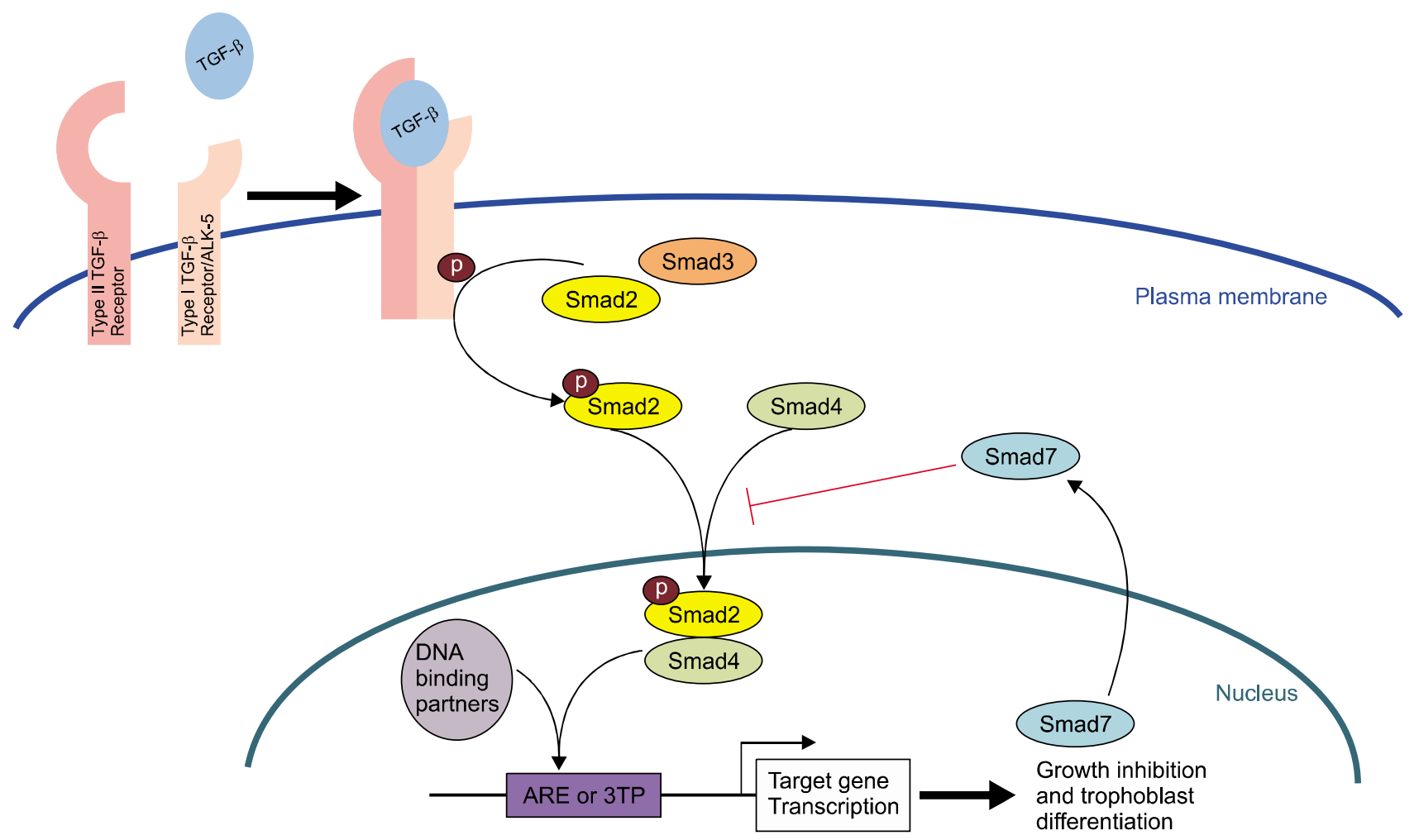

Fig. 5. TGF- $\beta$ induces Smad2 Phosphorylation, ARE Induction, and Trophoblast Differentiation Diagrammatic representation of the TGF- $\beta$ signaling pathway in SM10 growth inhibition and trophoblast differentiation. The ligand, TGF- $\beta$, binds to cognate receptors and triggers activation via the TGF- $\beta$ Type I receptor (ALK-5) to induce the phosphorylation of Smad2. Phospho-Smad2, via classically presumptive Smad 4 binding, triggers the transactivation of ARE response elements in target genes that inhibit cell growth and promote labyrinthine trophoblast differentiation. Smad 7 acts as a classical negative feedback inhibitor for the TGF- $\beta$ signaling pathway. 
forms were able to induce trophoblast progenitor cell differentiation; while other members of the TGF- $\beta$ superfamily, Nodal and Activin A, were not. Previous work in trophoblast stem (TS) cells showed that Actvin A prolonged proliferation and promoted differentiation along the labyrinth lineage; whereas TGF- $\beta$ promoted labyrinth differentiation, but did not prolong proliferation (38). The inability of Activin A to differentiate SM10 cells may be, in part, due to the more committed nature of these progenitor cells, compared to TS cells, which are capable of differentiating into all trophoblast lineages. In addition, our data indicate that TGF- $\beta$ induced differentiation can be mediated through the ALK5 receptor with subsequent phosphorylation of Smad2. Our data further indicate that the TGF- $\beta$ /phospho-Smad2 signal is mediated via the Activin Response Element (ARE) in order to regulate downstream targets involved in cell growth and trophoblast differentiation in response to TGF- $\beta$ in labyrinthine trophoblast cells. ARE activation in the presence of TGF- $\beta$ can be inhibited by upregulation of Smad7, which is known to inhibit the activation of Smad2 and Smad3. In summary, our studies identify an important regulatory signal transduction pathway in SM10 cells that serves as a model of labyrinthine trophoblast progenitor differentiation (Fig. 5).

\section{Acknowledgments}

TGF- $\beta 2$ was a kind gift from Steven Ledbetter of Genzyme, Inc., Boston, Massachusetts. The ARE-lux reporter was provided by Dr. Malcolm Whitman of Harvard Medical School, Boston, Massachusetts. The plasmid pCMV-hFAST-1 was provided by Dr. Bert Vogelstein of Johns Hopkins Medical School, Baltimore, Maryland. The pRK5-Smad2, pXIX-Smad3, and pRK5-Smad7 plasmid constructs were kindly provided by Dr. Rik Derynck, University of California San Francisco, San Francisco, California. Rabbit polyclonal anti-phospho-Smad3 was a kind gift from Dr. Ed Leof of the Mayo Clinic, Rochester, Minnesota. The Glutl-lux reporter was kindly provided by Dr. Amit Maity of the University of Pennsylvania, Philadelphia, Pennsylvania.

\section{Funding}

This work was supported in part by funding from the Biomedical Sciences Ph.D. Program (REA, KS), The Wright State University Endowment for Research on Pregnancy Associated Disorders (www.wright.edu/give/ pregnancyassociateddisorders), and The National Institutes of Health NICHD-R01 HD059969-(TLB).

\section{Potential Conflict of Interest}

The authors have no conflicting financial interest.

\section{References}

1. Vaughan OR, Rosario FJ, Powell TL, Jansson T. Regulation of placental amino acid transport and fetal growth. Prog Mol Biol Transl Sci 2017;145:217-251

2. Adelman DM, Gertsenstein $M$, Nagy A, Simon MC, Maltepe E. Placental cell fates are regulated in vivo by HIF-mediated hypoxia responses. Genes Dev 2000;14: 3191-3203

3. Ganguly A, Touma M, Thamotharan S, De Vivo DC, Devaskar SU. Maternal calorie restriction causing uteroplacental insufficiency differentially affects mammalian placental glucose and leucine transport molecular mechanisms. Endocrinology 2016;157:4041-4054

4. Shaarawy M, El Meleigy M, Rasheed K. Maternal serum transforming growth factor beta-2 in preeclampsia and eclampsia, a potential biomarker for the assessment of disease severity and fetal outcome. J Soc Gynecol Investig 2001;8:27-31

5. Xu J, Sivasubramaniyam T, Yinon Y, Tagliaferro A, Ray J, Nevo O, Post M, Caniggia I. Aberrant TGF $\beta$ signaling contributes to altered trophoblast differentiation in preeclampsia. Endocrinology 2016;157:883-899

6. Gormley M, Ona K, Kapidzic M, Garrido-Gomez T, Zdravkovic T, Fisher SJ. Preeclampsia: novel insights from global RNA profiling of trophoblast subpopulations. Am J Obstet Gynecol 2017;217:200.e1-200.e17

7. Massagué J. TGF $\beta$ signalling in context. Nat Rev Mol Cell Biol 2012;13:616-630

8. Brown TL, Patil S, Howe PH. Analysis of TGF-beta-inducible apoptosis. Methods Mol Biol 2000;142:149-167

9. Larsson J, Goumans MJ, Sjöstrand LJ, van Rooijen MA, Ward D, Levéen P, Xu X, ten Dijke P, Mummery CL, Karlsson S. Abnormal angiogenesis but intact hematopoietic potential in TGF-beta type I receptor-deficient mice. EMBO J 2001;20:1663-1673

10. Oshima M, Oshima H, Taketo MM. TGF-beta receptor type II deficiency results in defects of yolk sac hematopoiesis and vasculogenesis. Dev Biol 1996;179:297-302

11. Budi EH, Duan D, Derynck R. Transforming growth Factor- $\beta$ receptors and smads: regulatory complexity and functional versatility. Trends Cell Biol 2017;27:658-672

12. Goumans MJ, Mummery C. Functional analysis of the TGFbeta receptor/Smad pathway through gene ablation in mice. Int J Dev Biol 2000;44:253-265

13. Tojo $M$, Takebe A, Takahashi S, Tanaka K, Imamura $T$, Miyazono K, Chiba T. Smad7-deficient mice show growth retardation with reduced viability. J Biochem 2012;151:621631

14. Patil S, Wildey GM, Brown TL, Choy L, Derynck R, Howe PH. Smad7 is induced by CD40 and protects WEHI 231 B-lymphocytes from transforming growth factor-beta -induced growth inhibition and apoptosis. J Biol Chem 2000;275: 


\section{3-38370}

15. Soncin F, Natale D, Parast MM. Signaling pathways in mouse and human trophoblast differentiation: a comparative review. Cell Mol Life Sci 2015;72:1291-1302

16. Watson ED, Cross JC. Development of structures and transport functions in the mouse placenta. Physiology (Bethesda) 2005;20:180-193

17. Simmons DG, Natale DR, Begay V, Hughes M, Leutz A, Cross JC. Early patterning of the chorion leads to the trilaminar trophoblast cell structure in the placental labyrinth. Development 2008;135:2083-2091

18. Sharma RK. Mouse trophoblastic cell lines: I--Relationship between invasive potential and TGF-beta 1. In Vivo 1998; $12: 431-440$

19. Selesniemi K, Reedy M, Gultice A, Guilbert LJ, Brown TL. Transforming growth factor-beta induces differentiation of the labyrinthine trophoblast stem cell line SM10. Stem Cells Dev 2005;14:697-711

20. Selesniemi K, Albers RE, Brown TL. Id2 Mediates differentiation of labyrinthine placental progenitor cell line, SM10. Stem Cells Dev 2016;25:959-974

21. Waker CA, Albers RE, Pye RL, Doliboa SR, Wyatt CN, Brown TL, Mayes DA. AMPK knockdown in placental labyrinthine progenitor cells results in restriction of critical energy resources and terminal differentiation failure. Stem Cells Dev 2017;26:808-817

22. Hocevar BA, Brown TL, Howe PH. TGF-beta induces fibronectin synthesis through a c-Jun N-terminal kinase-dependent, Smad4-independent pathway. EMBO J 1999;18:1345-1356

23. Cárcamo J, Weis FM, Ventura F, Wieser R, Wrana JL, Attisano L, Massagué J. Type I receptors specify growth-inhibitory and transcriptional responses to transforming growth factor beta and activin. Mol Cell Biol 1994;14: 3810-3821.

24. Wang G, Matsuura I, He D, Liu F. Transforming growth factor-\{beta\}-inducible phosphorylation of Smad3. J Biol Chem 2009;284:9663-9673

25. Caserta TM, Smith AN, Gultice AD, Reedy MA, Brown TL. $\mathrm{Q}-\mathrm{VD}-\mathrm{OPh}$, a broad spectrum caspase inhibitor with potent antiapoptotic properties. Apoptosis 2003;8:345-352

26. Selesniemi K, Brown TL. Metafectene Technical Note-SM10 transfection [Internet]. 2004. Available from: http://www. biontex.com/media/references/SM10_transfection_plasmid_ DNA_Metafectene_Biontex_Browne2.pdf.
27. Doran DM, Kulkarni-Datar K, Cool DR, Brown TL. Hypoxia activates constitutive luciferase reporter constructs. Biochimie 2011;93:361-368

28. Kitagawa T, Masumi A, Akamatsu Y. Transforming growth factor-beta 1 stimulates glucose uptake and the expression of glucose transporter mRNA in quiescent Swiss mouse 3T3 cells. J Biol Chem 1991;266:18066-18071

29. Inoki K, Haneda $M$, Maeda S, Koya D, Kikkawa R. TGF-beta 1 stimulates glucose uptake by enhancing GLUT1 expression in mesangial cells. Kidney Int 1999;55:1704-1712

30. Inman GJ, Nicolás FJ, Callahan JF, Harling JD, Gaster LM, Reith AD, Laping NJ, Hill CS. SB-431542 is a potent and specific inhibitor of transforming growth factor-beta superfamily type I activin receptor-like kinase (ALK) receptors ALK4, ALK5, and ALK7. Mol Pharmacol 2002; 62:65-74

31. Weiss A, Attisano L. The TGFbeta superfamily signaling pathway. Wiley Interdiscip Rev Dev Biol 2013;2:47-63

32. Schmierer B, Hill CS. TGFbeta-SMAD signal transduction: molecular specificity and functional flexibility. Nat Rev Mol Cell Biol 2007;8:970-982

33. Moses HL, Roberts AB, Derynck R. The discovery and early days of TGF- $\beta$ : a historical perspective. Cold Spring Harb Perspect Biol 2016;8:a021865 doi: 10.1101/cshperspect. a021865

34. Wilkes MC, Murphy SJ, Garamszegi N, Leof EB. Cell-type-specific activation of PAK2 by transforming growth factor beta independent of Smad2 and Smad3. Mol Cell Biol 2003;23:8878-8889

35. Zhou S, Zawel L, Lengauer C, Kinzler KW, Vogelstein B. Characterization of human FAST-1, a TGF beta and activin signal transducer. Mol Cell 1998;2:121-127

36. Zawel L, Dai JL, Buckhaults P, Zhou S, Kinzler KW, Vogelstein B, Kern SE. Human Smad3 and Smad4 are sequence-specific transcription activators. Mol Cell 1998;1: 611-617

37. Yan X, Liao H, Cheng M, Shi X, Lin X, Feng XH, Chen YG. Smad7 protein interacts with receptor-regulated smads (R-Smads) to inhibit transforming growth factor- $\beta$ (TGF$\beta)$ /smad signaling. J Biol Chem 2016;291:382-392

38. Natale DR, Hemberger M, Hughes M, Cross JC. Activin promotes differentiation of cultured mouse trophoblast stem cells towards a labyrinth cell fate. Dev Biol 2009; 335:120-131 